\title{
Lung function in workers exposed to polyvinyl chloride dust
}

\author{
C P CHIVERS*, C LAWRENCE-JONES $†$, AND G M PADDLE
}

From Imperial Chemical Industries Ltd, Wilmslow, Cheshire $S K 91 Q B, U K$

\begin{abstract}
Several reported studies on the effects of polyvinyl chloride (PVC) dust in animals and man have been conflicting. The present study of the ventilatory function of 509 male workers exposed to PVC dust was made in 1977. Altogether 104 men exposed to PVC dust only, 112 men exposed to non-chlorinated solvents only, and 293 men exposed to a mixture of both completed the MRC questionnaire on respiratory function and performed simple spirometric tests (forced expiratory volume in one second and forced vital capacity). No differences were found between the three groups after allowance was made for age, height, and smoking. When exposure and smoking effects were considered separately, the latter was shown to be the dominant cause of reduced lung function. In this study work with PVC dust has not produced deleterious effects on ventilatory function.
\end{abstract}

Polyvinyl chloride (PVC), a large tonnage raw material of fundamental importance to the plastics industry, is a white powder that was until recently considered to be inert. The basic material is formed from its monomer, the gas vinyl chloride (VCM). Although VCM and PVC have been synthesised for over 30 years, it is only in the past 10 years that the sinister nature of VCM has become apparent. VCM has been found to produce a wide spectrum of clinical conditions, the most important being angiosarcoma of the liver in workers exposed to high concentrations of the gas in PVC production plants. This was discovered in 1974 and because a small quantity of the gas is carried forward with the PVC powder to its containers, and thus to the formulating industries the effects, if any, of the PVC powder came into question. The chance of finding effects similar to those associated with VCM is considered remote, since the concentrations are greatly reduced. The possibility of pulmonary changes being caused by inhalation of the dust however, has led to experimental and clinical research.

The cytotoxicity of various polymer dusts, including PVC, to suspensions of rat alveolar and peritoneal macrophages in culture ${ }^{1}$ indicated that

*Now retired.

$\dagger$ Present appointment: Division Medical Officer, ICI Ltd, Millbank, London.

Received 20 December 1978

Accepted 14 August 1979
PVC caused deaths of cells similar in amount to kaolin, magnesium trisilicate, and polyethylene. These materials produced less than $2 \%$ fibrogenicity compared with over $10 \%$ for asbestos.

On such evidence PVC had been considered inert and therefore incapable of producing lung changes. Szende et $a l^{2}{ }^{2}$ however, reported radiological and clinical evidence of a moderately diffuse fibrosis in a man aged 31 who had been exposed to PVC dust for only one year. This clinical information led Frongia et $\mathrm{al}^{3}$ to carry out an experimental long-term study of the effect on guinea pigs and rats of breathing the same PVC dust as workers in the same area of the bagging plant of a factory. In this area the PVC concentration averaged 10000 particles $/ \mathrm{cm}^{3}$, gradings being around one micron. The animals were exposed for 24 hours a day for periods between two and seven months continually. Lung histology in the two types of animals showed differing responses to the dust at the beginning of the tests, but subsequently a granulomatous reaction was reported in both species.

Similar experimental studies in white rats also suggested a chronic pneumonia followed later by inflammation of the bronchial tree with mild fibrotic processes in the lung. ${ }^{4}$ This study among others prompted Vertkin and Mamontov ${ }^{5}$ to examine workers manufacturing PVC products. There were no abnormal clinical findings in the overwhelming majority of patients. Estimations of vital capacity, forced expiratory volume in one second $\left(\mathrm{FEV}_{1}\right)$, and maximal voluntary ventilation 
were performed on 64 workers. Only one vital capacity was excessively low, $50 \%$ being at least $15 \%$ better than normal. Long-exposure employees (6-12 years) were found to have $\mathrm{FEV}_{1} /$ forced vital capacity (FVC) ratios less than $70 \%$ with clinical manifestations of bronchitis and emphysema. In at least $50 \%$ of cases the maximum voluntary ventilation exceeded standard values. Hydrogen chloride gas as a possible factor in these effects was considered, and the importance of functional changes must be judged on the results of further observations. There was no mention of smoking as a factor.

In 1975 Miller et al $^{6}$ examined the lung function of 267 workers currently employed and 87 previously employed in work exposed to both VCM and PVC. FVC and FEV 1 together with mid-expiratory flow (MMF) were measured and compared with the predicted values of Morris et al. ${ }^{7}$ Smoking habits were also recorded. Non-smokers were defined as those who smoked less than one cigarette a day, had smoked less than 10 cigarettes a day for up to six months more than two years ago, or had smoked only cigars and pipes. Although prevalence of impaired lung function was statistically different between smokers and non-smokers for those aged 39 and younger, smoking was not found to be a significant factor above this age. In both smokers and non-smokers when exposed to PVC dust for more than 20 years the $\mathrm{FEV}_{1} / \mathrm{FVC}$ ratio was reduced. Though impaired flow was more frequent with increasing duration of exposure, volume impairment was not so related. Since there were only seven non-smokers in the group, any deductions about their performance were not thought to be justified.

In 1978 Arnaud et al ${ }^{8}$ described pneumoconiosis in a 53-year-old man who had been exposed for 23 years to PVC in the bagging area of a vinyl chloride polymerisation plant. The histological findings from the lung biopsy specimen of moderate diffuse fibrosis and several small focal lesions were identical to those reported by Szende $e t \mathrm{al}^{2}$ and those produced experimentally by Frongia et al. $^{3}$ Despite the radiological changes the patient had only a slight reduction in his vital capacity and no reduction in gas transfer factor, which suggested that the fibrosis was not of much functional significance.

Exposure to PVC and VCM together was thought to be important by Lilis et al, ${ }^{9}$ who found greater effect on lung function when these were combined than with either substance by itself. They studied workers in three plants, all of whom had mixed exposure to differing concentrations. Radiological lung fibrosis and altered pulmonary function tests were found in 96 workers exposed to PVC dust, the changes being more pronounced in people with long exposure. Smoking histories were related to abnormal chest radiographs, but no consistent link was found between these and abnormal lung function. Smoking and age were both related to obstructive lung function changes and because of this it was difficult to isolate the specific effect of occupational vital capacity and exposure to PVC.

In view of this conflicting evidence about a material generally accepted as inert, and because of the large number of people in contact with it in so many industries, it was thought that a large-scale study should be initiated to investigate lung function in workers handling PVC.

\section{Material and methods}

\section{FACTORY}

The works used PVC for over 30 years, originally to manufacture coated fabrics, and recently also for plastic-coated wall coverings. The PVC powder is mixed with several additives such as plasticisers, stabilisers, and pigments. Thus this is a user study in which there may be exposure to low concentrations of other chemicals. Whether the final product is rigid or flexible, spread on to or laminated with supporting sheet, calendered or extruded, the fundamental technology is the same.

JOBS

Jobs range from handling raw materials and minding machines that formulate the PVC mixes to attending to the printing process for wall coverings. A few jobs, which include manual handling of raw materials, are physically demanding for short periods but generally they are semi-sedentary. Once plasticised, the covering or formed sheet is machined in various ways. During these operations, employees are exposed to minimal amounts of dust but also to some solvent vapour. In the final stages of the process employees are exposed to no dust and to minimal amounts of solvent vapour.

\section{DUST EXPOSURE}

Potential exposure levels to PVC can be gauged from the following annual tonnages: 1951, 1502; 1956, $2622 ; 1961,3671 ; 1966,6735 ; 1971,12218$; and 1974, 13957

Nevertheless, although these figures give an impression of the size and growth of the operation, it is considered that the present conditions with fewer manual operations are much better than formerly, despite the higher tonnage of PVC used. There is little quantitative information on which to base this judgement as records of atmospheric levels of PVC dust have been kept only since 1975. 
Table 1 Mean dust concentrations

\begin{tabular}{llll}
\hline & $\begin{array}{l}1975 \\
\left(\mathrm{mg} / \mathrm{m}^{3}\right)\end{array}$ & $\begin{array}{l}1976 \\
\left(\mathrm{mg} / \mathrm{m}^{3}\right)\end{array}$ & $\begin{array}{l}1978 \\
\text { Respirable fraction } \\
\left(\mathrm{mg} / \mathrm{m}^{3}\right)\end{array}$ \\
\hline $\begin{array}{l}\text { Poorly-ventilated } \\
\text { mixing room }\end{array}$ & 5.9 & 4.0 & $0.4(0.3)$ \\
$\begin{array}{c}\text { Well-ventilated } \\
\text { mixing room }\end{array}$ & - & 1.5 & $0.2(0.03)$ \\
$\begin{array}{c}\text { Bag disposal } \\
\text { Loading without } \\
\text { ventilation }\end{array}$ & - & 0.9 & $0.2(0.09)$ \\
$\begin{array}{c}\text { Background level } \\
\text { aackound }\end{array}$ & - & - & $11.5(1.7)$ \\
\hline
\end{tabular}

In 1975,1976 , and 1978 studies of the PVC mixing areas were carried out using static personal monitoring devices. Table 1 summarises the results while table 2 shows particle size distribution and density. Tests for VCM almost invariably showed "none detectable," but occasionally 1-3 ppm were found.

\section{PULMONARY FUNCTION STUDY}

Lung function tests were offered to all men working in the production areas associated with PVC and solvents. Of these 557 employees, 17 refused to take part and 31 were unavailable at the time of the tests, 23 being sick, four on holiday, three having left, and one being due for retirement. Since the population comprised the largest group in the works, leaving no comparable static non-exposed group available as controls, it was thought justified to use as controls those exposed to low levels of solvents. Therefore in the analyses the population is divided into three groups: those exposed only to PVC dust, those exposed to solvents, and those exposed to both. All the men were of the same racial origin. Table 3 shows the type of exposure of the three groups, and table 4 gives their exposure in years.

\section{PROCEDURE}

All the 509 volunteers were examined within one month in early summer 1977. Each rested for at least 15 minutes while he filled in a Medical Research Council (MRC) questionnaire with help from one of three trained State registered nurses. When the subject was completely rested, ventilatory function was

Table 2 Particle size distribution by percentage. (Density of PVC particles $=1 \cdot 4$ )

\begin{tabular}{lll}
\hline $\begin{array}{l}\text { Size } \\
(\mu)\end{array}$ & Non-operating conditions & Operating conditions \\
\hline$>1$ & 19.3 & \\
$>2$ & 8.5 & $26 \cdot 6$ \\
$>3$ & 1.9 & $9 \cdot 8$ \\
$>5$ & 0.2 & 3.6 \\
$>10$ & 0.03 & $0 \cdot 3$ \\
\hline
\end{tabular}

Table 3 Exposure to dust, solvents, or both.

(Percentages in parentheses)

\begin{tabular}{lcrlrl}
\hline $\begin{array}{l}\text { Exposure } \\
\text { level }\end{array}$ & \multicolumn{5}{l}{ Exposure group } \\
\cline { 2 - 6 } & Solvents & \multicolumn{1}{l}{ Dust } & \multicolumn{2}{l}{ Both } & Total \\
\hline Continuous & $74(66)$ & $45(43)$ & $120(41)$ & 239 \\
Regular & $22(20)$ & $25(24)$ & $64(22)$ & 111 \\
Occasional & $16(14)$ & $34(33)$ & $109(37)$ & 159 \\
Total & $112(100)$ & $104(100)$ & $293(100)$ & 509 \\
\hline
\end{tabular}

measured with a calibrated Vitalograph following a standard routine. Measurement of barometric pressure and temperature were made at each session. All readings were recorded on the ATPS scale and corrected to BTPS by the calculation given by Cotes. ${ }^{10}$ Eleven subjects unable to complete the trials for psychological or physiological reasons were excused three sample readings, and estimates of the FEV 1 and FVC were obtained from those tracings performed.

In analysing the pulmonary function data the heights, ages, and smoking habits of the individuals were taken into account. Height and age were allowed for by expressing the recorded figures as percentages of the prediction equation given by Cotes et al. ${ }^{11}$ As this equation was derived from data for healthy non-smokers, it would not be expected that the study population in which there was a majority of smokers would achieve an average of $100 \%$. Smoking habits have been allowed for by dividing the population into three categories according to their replies to the MRC smoking questionnaire: those who had never smoked; heavy smokers who smoked, or who had only recently ceased smoking 15 or more cigarettes a day; and all others, whether smokers or ex-smokers. The three groups have been called non-smokers, heavy smokers, and others.

\section{Results}

The results for the three exposure groups irrespective of smoking habits are summarised in table 5. As the average heights and ages of the three groups are

Table 4 Years of exposure. (Percentages in parentheses)

\begin{tabular}{|c|c|c|c|c|}
\hline \multirow{2}{*}{$\begin{array}{l}\text { Years in } \\
\text { plant }\end{array}$} & \multicolumn{4}{|c|}{ Exposure group } \\
\hline & Solvents & Dust & Both & Total \\
\hline $\begin{array}{rl}<5 & 5-9 \\
& 10-14 \\
\geqslant & 15\end{array}$ & $\begin{array}{ll}43 & (38) \\
29 & (26) \\
18 & (16) \\
22 & (20)\end{array}$ & $\begin{array}{ll}45 & (43) \\
28 & (27) \\
20 & (19) \\
11 & (11)\end{array}$ & $\begin{aligned} 111 & (38) \\
82 & (28) \\
60 & (20) \\
40 & (14)\end{aligned}$ & $\begin{array}{r}199 \\
139 \\
98 \\
73\end{array}$ \\
\hline Total & $112(100)$ & $104(100)$ & $293(100)$ & 509 \\
\hline
\end{tabular}


Table 5 Comparison of exposure groups

\begin{tabular}{|c|c|c|c|}
\hline & Dust & Solvents & Both \\
\hline No" & $\begin{array}{l}104 \\
44 \cdot 8(11 \cdot 5)\end{array}$ & $\begin{array}{l}112 \\
43.6(12.8)\end{array}$ & $\begin{array}{l}293 \\
43 \cdot 0(11 \cdot 2)\end{array}$ \\
\hline $\begin{array}{l}\text { mean (SD) } \\
\text { FEV }_{1}(\mathrm{ml}): \text { mean } \\
\text { FVC }(\mathrm{ml}): \text { mean } \\
\text { FEV }_{1}(\% \text { predicted }):\end{array}$ & $\begin{array}{l}173 \cdot 0 \quad(7 \cdot 4) \\
3439 \\
4313\end{array}$ & $\begin{array}{l}174 \cdot 2 \quad(6 \cdot 4) \\
3436 \\
4441\end{array}$ & $\begin{array}{l}174 \cdot 5 \quad(6 \cdot 9) \\
3533 \\
4502\end{array}$ \\
\hline $\begin{array}{c}\text { mean (SD) } \\
\text { FVC (\% predicted): }\end{array}$ & $98.9(17 \cdot 2)$ & $95.6(23.0)$ & $98.2(19.4)$ \\
\hline $\begin{array}{l}\text { mean (SD) } \\
\text { Years in plant: }\end{array}$ & $98.5(15.0)$ & $98.7(18.4)$ & $99.5(18.5)$ \\
\hline mean (SD) & $7.0 \quad(6.0)$ & $9 \cdot 5 \quad(9 \cdot 6)$ & $8.5 \quad(7.0)$ \\
\hline
\end{tabular}

so similar the absence of a dust effect is illustrated both by the recorded data and by their conversion to percentages of predicted. The extent of exposure can be gauged from the data for the duration of employment in the plants.

The smoking effect, irrespective of exposure group, is clearly shown in table 6, in which, because of age differences between groups, only converted figures are shown. There is a very pronounced disparity between the results for non-smokers and heavy smokers, and the results for the others are intermediate.

As this large smoking effect may conceal an exposure effect, and as there may be a synergistic effect of smoking and exposure, smoking and exposure effects were compared (table 7). Although two of the non-smoking groups are quite small, there is no deleterious effect of dust evident in any of the smoking groups, and the smoking effect is the same in each exposure group.

Finally, the effect of duration of exposure to PVC dust was considered when the effects of age, height, and smoking, typified by cumulative cigarette consumption, had been taken into account. Analysis showed that length of service had a negligible effect on the ventilatory function of those exposed to PVC dust, and supported the conclusion that their respiratory health is better than that of the controls.

Table 6 Comparison of smoking groups

\begin{tabular}{|c|c|c|c|}
\hline & Non-smokers & Heavy smokers & Others \\
\hline $\begin{array}{l}\text { No } \\
\text { Age: mean (SD) } \\
\text { Height }(\mathrm{cm}):\end{array}$ & $\begin{array}{l}87 \\
40 \cdot 2(11 \cdot 8)\end{array}$ & $\begin{array}{l}215 \\
43 \cdot 3(11 \cdot 8)\end{array}$ & $\begin{array}{l}207 \\
45 \cdot 2(11 \cdot 2)\end{array}$ \\
\hline $\begin{array}{l}\text { mean (SD) } \\
\text { FEV }_{1}(\% \text { predicted }):\end{array}$ & $174 \cdot 5 \quad(7 \cdot 1)$ & $173.7 \quad(6.9)$ & $174.2 \quad(6.9)$ \\
\hline $\begin{array}{l}\text { mean (SD) } \\
\text { FVC ( } \% \text { predicted): }\end{array}$ & $103.2(18 \cdot 4)$ & $94 \cdot 2(20 \cdot 4)$ & $99 \cdot 2(19 \cdot 2)$ \\
\hline $\begin{array}{l}\text { mean (SD) } \\
\text { Years in plant: }\end{array}$ & $102 \cdot 6(17 \cdot 2)$ & $97 \cdot 5(18.0)$ & $99 \cdot 4(17 \cdot 7)$ \\
\hline mean (SD) & $7 \cdot 8 \quad(6 \cdot 8)$ & $8 \cdot 4 \quad(7 \cdot 2)$ & $8.7 \quad(8.0)$ \\
\hline
\end{tabular}

Table 7 Comparisons of exposure and smoking classifications

\begin{tabular}{|c|c|c|c|}
\hline & Dust & Solvents & Both \\
\hline $\begin{array}{l}\text { No } \\
\text { Age: mean (SD) } \\
\text { Height (cm): }\end{array}$ & $\begin{array}{l}\text { Non-smokers } \\
16 \\
38.9(11 \cdot 3)\end{array}$ & $\begin{array}{l}18 \\
42 \cdot 5(15 \cdot 1)\end{array}$ & $\begin{array}{l}53 \\
39 \cdot 8(10 \cdot 7)\end{array}$ \\
\hline $\begin{array}{l}\text { mean (SD) } \\
\text { FEV }_{1}(\% \text { predicted }):\end{array}$ & $174 \cdot 2 \quad(9 \cdot 1)$ & $176.0 \quad(5 \cdot 1)$ & $174 \cdot 2 \quad(6.9)$ \\
\hline $\begin{array}{l}\text { mean (SD) } \\
\text { FVC ( } \% \text { predicted): } \\
\text { mean (SD) }\end{array}$ & $107 \cdot 5(11.8)$ & $101.0(25.0)$ & $\begin{array}{l}102 \cdot 6(17 \cdot 5) \\
102 \cdot 7(18 \cdot 1)\end{array}$ \\
\hline $\begin{array}{l}\text { Years in plant: } \\
\text { mean (SD) }\end{array}$ & $\begin{array}{cl}5.8 & (4 \cdot 8) \\
\text { Heavy smokers }\end{array}$ & $8 \cdot 8 \quad(9 \cdot 6)$ & $8 \cdot 1 \quad(6 \cdot 2)$ \\
\hline $\begin{array}{l}\text { No } \\
\text { Age: mean (SD) } \\
\text { Height }(\mathrm{cm}):\end{array}$ & $\begin{array}{l}37 \\
43 \cdot 6(12 \cdot 1)\end{array}$ & $\begin{array}{l}46 \\
42 \cdot 7(12 \cdot 7)\end{array}$ & $\begin{array}{l}132 \\
43 \cdot 3(11 \cdot 4)\end{array}$ \\
\hline $\begin{array}{l}\text { mean (SD) } \\
\text { FEV }_{1}(\% \text { predicted): } \\
\text { mean (SD) } \\
\text { FVC ( } \% \text { predicted): }\end{array}$ & $172 \cdot 2 \quad(6 \cdot 6)$ & $\begin{array}{l}174.0(6.6) \\
91.4(23.7)\end{array}$ & $\begin{array}{r}174.2 \quad(6.9) \\
95.0(19.8)\end{array}$ \\
\hline $\begin{array}{l}\text { mean (SD) } \\
\text { Years in plant: }\end{array}$ & $98.4(14.9)$ & $97 \cdot 1(17 \cdot 6)$ & $97 \cdot 3(19 \cdot 0)$ \\
\hline mean (SD) & $\begin{array}{c}7 \cdot 5 \quad(5 \cdot 5) \\
\text { Other smokers }\end{array}$ & $8.9 \quad(8.0)$ & $8 \cdot 5 \quad(7 \cdot 3)$ \\
\hline $\begin{array}{l}\text { No } \\
\text { Age: mean (SD) } \\
\text { Height }(\mathrm{cm}):\end{array}$ & $\begin{array}{l}51 \\
47 \cdot 7(10 \cdot 4)\end{array}$ & $\begin{array}{l}48 \\
44 \cdot 9(12 \cdot 2)\end{array}$ & $\begin{array}{l}108 \\
44 \cdot 3(11 \cdot 0)\end{array}$ \\
\hline $\begin{array}{l}\text { mean (SD) } \\
\text { FEV }_{1}(\% \text { predicted): } \\
\text { mean (SD) }\end{array}$ & $173.2 \quad(7 \cdot 4)$ & $174.0 \quad(6.6)$ & $175.0 \quad(6.6)$ \\
\hline $\begin{array}{l}\text { FVC (\% predicted): } \\
\text { mean (SD) } \\
\text { Years in plant: }\end{array}$ & $96.9(15.6)$ & $99 \cdot 3(19 \cdot 3)$ & $100 \cdot 6(17 \cdot 9)$ \\
\hline $\begin{array}{l}\text { ears in plant: } \\
\text { mean (SD) }\end{array}$ & $7 \cdot 1 \quad(6 \cdot 7)$ & $10.4(11.0)$ & $8.7 \quad(6.9)$ \\
\hline
\end{tabular}

Although it is difficult to draw conclusions from cross-sectional studies of lung abnormalities, ${ }^{12}$ this investigation of ventilatory function in workers exposed to PVC dust over a prolonged period has provided no evidence of lung damage.

We thank Mr S B Rawlinson, industrial hygiene officer, and Mr D J Seaborn (Central Toxicological Laboratory) for carrying out the environmental monitoring and the medical staff who assisted with this work.

\section{References}

${ }^{1}$ Styles JA, Wilson J. Comparison between in vitro toxicity of polymer and mineral dusts and their fibrogenicity. Ann Occup Hyg 1973;16:241-50.

${ }^{2}$ Szende B, Lapis K, Nemes A, Pinter A. Pneumoconiosis caused by inhalation of polyvinyl chloride dust. Med Lav $1970 ; 61: 433-6$.

${ }^{3}$ Frongia N, Spinazzola A, Bucarelli A. Experimental pulmonary lesions from prolonged inhalations of PVC dust in a work environment. Med Lav 1974;65:321-42.

4 Golovatyuk AP. The effect of PVC dust in industry and experimental conditions. Vrach delo 1963;11:107.

5 Vertkin YI, Mamontov JR. On the state of the bronchopulmonary system in workers engaged in the manufacture of PVC products. Gig Tr Prof Zabol 1970;14:29-32. 
- Miller A, Tierstein AS, Chuang M, Selikoff IJ. Changes in pulmonary function in workers exposed to vinyl chloride and polyvinyl chloride. Ann NY Acad Sci 1975; 246:42-52.

? Morris JF, Kosk A, Johnson LC. Spirometric standards for healthy non-smoking adults. Am Rev Respir Dis 1971;103:57-67.

${ }^{8}$ Arnaud A, Pommier de Santi P, Garbe L, Payan H, Charpin J. Polyvinyl chloride pneumoconiosis. Thorax 1978;33:19-25.

- Lilis R, Anderson H, Nicholson WJ, Daum S, Fishbein
AS, Selikoff IJ. Prevalence of disease amongst vinyl chloride and polyvinyl chloride workers. Ann NY Acad Sci $1975 ; 246: 22-41$.

10 Cotes JE. Lung function. 3rd ed. Oxford: Blackwell, 1975: 21.

${ }^{11}$ Cotes JE, Rissiter CE, Higgins ITT, Gilson JC. Average normal values for forced respiratory volume in white Caucasian males. Br Med J 1966;1:1016-9.

${ }^{12}$ Fletcher C, Peto R, Tinker C, Speizer FE. The natural history of chronic bronchitis and emphysema. London: Oxford University Press, 1976:35-51. 